\title{
ANALISIS PERBANDINGAN KINERJA KEUANGAN PADA PD BPR BKK KEBUMEN DAN PT BPR DANA MITRA SEJAHTERA KEBUMEN
}

\author{
Erma Reiza Damayanti \\ ermareizadamayanti17@gmail.com \\ Universitas Ahmad Dahlan \\ Dyah Fitriani \\ dhifa_dhe@yahoo.com \\ Universitas Ahmad Dahlan
}

\begin{abstract}
ABSTRAK
The research aims to compare health of BPR in terms of financial performance. The object of the research is PD BPR BKK Kebumen and PT BPR Dana Mitra Sejahtera for a period of 2012,2013 and 2014. Banking financial performance used on this research is on financial aspects that be measured by the ratio of the suffciency minimum obligation (CAR), the ratio of the quality of assets productive (KAP), an allowance the formation of productive assets (PPAP), the ratio return on assets (ROA) that reflect the ability of a bank in generate profit, the ratio of BOPO ( the load operational against operational income) that reflects the burden of operational compared with earnings obtained, while for liquidity measured by CR and LDR. From this research obtained the results of that overall shows the level of financial performance of a healthy. The ratio CAR in PD BPR BKK Kebumen shows the average 15,21\% larger from PT BPR Dana Mitra Sejahtera that shows the average CAR $12,70 \%$ and both banks included in category of healthy. The rati of the quality of assets productive (KAP) in PD BPR BKK Kebumen shows the average 5,68\% larger than PT Dana Mitra Sejahtera which shows the average quality of assets productive $5,27 \%$ and both banks included in category of healthy. The ratio of PPAP inPD BPR BKK Kebumenthat shows the average 100\% and PT BPR Dana Mitra Sejahtera which shows the average $95,68 \%$ and both banks included in category of healthy. The ratio ROA in PD BPR BKK Kebumen shows the average 3,64\% larger than PT BPR Dana Mitra Sejahtera which shows the the average ROA 2,24\% and both banks included in category of healthy.the ratio of BOPO in PD BPR BKK Kebumen shows the average 72,13\% less than than funds PT BPR Dana Mitra Sejahtera which shows the average BOPO 75,68\% and both banks included in category of healthy. The ratio of CR in PD BPR BKK Kebumen shows the average 25,82\% larger from PT BPR Dana Mitra Sejahtera thatshows the average CR 21,02\% and both bank included in category of healthy. The ratio LDR in PD BPR BKK Kebumen shows the average 98,90\% and included in category of less healthy and this is different from PT BPR Dana Mitra Sejahtera that Shows the average $78,33 \%$ in categories healthy. The ratio of non performing loan (NPL) in PD BPR BKK Kebumen shows the average 3,87\% and dutifully included in the category of while from PT BPR Dana MitraSejahtera which shows the average NPL 5,25\% greater than that required in category 5\% so dutifully enough. Of a whole the assessment of the level second health BPR in PT BPR Dana Mitra Sejahtera it has value $99.90 \%$ better than PD BPR BKK kebumen in that it has value $99.05 \%$.
\end{abstract}

Keyword: Comparison of financial performance; profitability; liquidity; non performing loans; capital adequensy ratio; cash ratio; loan to deposite ratio. 


\section{PENDAHULUAN}

Menurut UU nomor 10 tahun 1998 tentang perbankan menyebutkan bank adalah badan usaha yang menghimpun dana dari masyarakat dalam bentuk simpanan dan menyalurkannya dalam bentuk kredit dan atau bentuk bentuk lainnya dalam rangka meningkatkan taraf hidup masyarakat banyak. Oleh karena itu bank merupakan lembaga intermediasi yang menghubungkan pihak-pihak yang kelebihan dana dengan pihak-pihak yang membutuhkan dana. Pihak-pihak yang kelebihan dana menyimpan uangnya di bank dalam bentuk tabungan atau dalam bentuk deposito sedangkan pihak-pihak yang membutuhkan dana menggunakan dana yang ada di bank dalam bentuk pinjaman/kredit.

Bank Indonesia (BI) merupakan bank sentral yang mempunyai tugas sebagai pemegang regulasi industri perbankan di Indonesia yang salah satu fungsinya adalah mengawasi operasional perbankan di Indonesia. Industri perbankan di Indonesia harus tunduk pada aturan BI agar kepercayaan masyarakat terhadap perbankan menjadi baik. Oleh karena itu Bank Indonesia menetapkan suatu ketentuan yang harus dipenuhi dan dilaksanakan oleh lembaga perbankan bahwa bank harus memenuhi tingkat kesehatan bank. Tingkat kesehatan bank adalah kondisi suatu bank dapat menjalankan kegiatan operasional dan dapat memenuhi kewajibannya (UU No 10 tahun 1998).

Penilaian kinerja keuangan bank dapat dilakukan dengan menganalisis laporan keuangan yang mencerminkan kinerja bank pada periode tertentu. Laporan keuangan periodik menggambarkan perubahan kinerja dari waktu ke waktu sehingga hasil analisis terhadap laporan keuangan tersebut dapat digunakan oleh pemangku kepentingan / stakeholder dalam pengambilan keputusan dan dapat digunakan pula sebagai upaya perbaikan untuk mengurangi resiko.

Kinerja keuangan perbankan dapat diukur dengan menggunakan rasio CAR (capital adequacy ratio) yaitu rasio kecukupan modal minimal bank dalam mencukupi kegiatan operasionalnya, rasio Kualitas Aktiva Produktif (KAP) yaitun kemampuan bank dalam mengelola aktiva/ kekayaan bank, Rasio Return on Asset (ROA) yang mencerminkan kemampuan bank dalam menghasilkan laba, rasio BOPO (Beban Operasional terhadap Pendapatan Operasional) yang mencerminkan beban operasional dibandingkan dengan pendapatan yang diperoleh.

Penelitian ini mengambil lokasi penelitian di PD BPR BKK Kebumen dan BPR Dana Mitra Sejahtera (BPR DMS). Kedua bank tersebut merupakan Bank Prekreditan Rakyat konvensional yang melakukan kegiatan utama perbankan yaitu menghimpun dan menyalurkan dana. Penghimpunan dana dilakukan dengan membuka pelayanan jasa simpanan berupa tabungan dan deposito berjangka dalam mata uang rupiah. Sedangkan penyaluran dana kepada masyarakat dengan memberikan jasa kredit atau pembiayaan kepada Usaha Menengah Kecil dan Mikro (UMKM).

Dalam kegiatan operasionalnya industri perbankan di kabupaten Kebumen menghadapi situasi perekonomian yang tidak menentu dan penuh ketidakpastian, hal ini akan mempengaruhi kondisi tingkat kesehatan perbankan. Faktor utama yang hampir dihadapi seluruh perbankan adalah membengkaknya jumlah kredit yang bermasalah dan kredit macet. Semakin banyak kredit bermasalah dan kredit macet yang muncul akan berdampak pada kesulitan perbankan dalam memberikan pelayanan perbankan.

Penelitian ini akan membandingkan kesehatan bank yang ditinjau dari aspek kinerja keuangan bank yang disyaratkan oleh BI pada bank milik pemerintah daerah Kabupaten Kebumen dengan bank 
yang dikelola oleh swasta sehingga diharapkan dapat memberikan gambaran riil faktor-faktor yang menyebabkan perbedaan kinerja keuangan perbankan yang dimiliki pemerintah dengan perbankan yang dikelola swasta.

Tujuan penelitian ini di antaranya: 1) untuk mengetahui perbandingan kinerja keuangan bank ditinjau dari kecukupan modal PD. BPR BKK KEBUMEN DAN PT BPR DANA MITRA SEJAHTERA KEBUMEN, 2) untuk mengetahui perbandingan kinerja keuangan bank ditinjau dari rasio KAP serta untuk mengetahui rasio PPAP PD. BPR BKK KEBUMEN DAN PT BPR DANA MITRA SEJAHTERA KEBUMEN, 3) untuk mengetahui perbandingan kinerja manajemen bank ditinjau dari rasio NPL PD. BPR BKK KEBUMEN DAN PT BPR DANA MITRA SEJAHTERA KEBUMEN, 4) untuk mengetahui perbandingan kinerja bank ditinjau dari tingkat Earning (rentabilitas) PD. BPR BKK KEBUMEN DAN PT BPR DANA MITRA SEJAHTERA KEBUMEN, 5) untuk mengetahui perbandingan kinerja bank ditinjau dari tingkat Likuiditas PD. BPR BKK KEBUMEN DAN PT BPR DANA MITRA SEJAHTERA KEBUMEN dan 6) untuk mengetahui perbandingan kinerja keuangan bank secara keseluruhan pada PD BPR BKK KEBUMEN DAN PT BPR DANA MITRA SEJAHTERA KEBUMEN.

\section{REVIEW LITERATUR DAN HIPOTESIS}

\section{Landasan Teori}

1. Bank

Pengertian bank menurut Undang-Undang Republik Indonesia No. 10 tahun 1998 tentang perbankan adalah badan usaha yang menghimpun dana dari masyarakat dalam bentuk simpanan dan menyalurkan kepada masyarakat dalam bentuk kredit dan atau bentuk-bantuk lainnya dalam rangka meningkatkan taraf hidup orang banyak.

2. Bank Perkreditan Rakyat

Pengertian bank perkreditan rakyat menurut Undang-Undang Republik Indonesia No. 10 tahun 1998 tentang perbankan adalah adalah bank yang melaksanakan kegiatan usaha secara konvensional atau berdasarkan prinsip syariah yang kegiatannya tidak memberikan jasa dalam lalu lintas pembayaran.

\section{Rasio KAP}

Perbankan sebagai lembaga pemberi jasa-jasa keuangan dalam lalu lintas pembayaran, maka bank memberikan berbagai fasilita kepada nasabah, loanable funds dari bank yang terbesar diberikan dalam bentuk kredit. Penilaian kualitas asset merupakan penilaian terhadap kondisi asset bank dan kemampuan manajemen dalam mengelola kredit. Aktiva produktif yaitu semua aktiva dalam rupiah maupun valuta asing yang dimiliki oleh bank dengan maksud untuk memperoleh penghasilan sesuai dengan fungsinya, sehingga kredit merupakan salah satu bentuk aktiva produktif (Susilo, 2000).

4. Rasio NPL

Pengelolaan aktiva produktif adalah bagian dari managemen asset yang juga mengatur tentang cash reserve (liquidity assets) dan fixed assets (aktiva tetap dan inventaris). Aktiva produktif yang dimiliki bank memiliki empat golongan yaitu lancar, kurang lancar, diragukan dan macet sesuai dengan kolektibilitasnya. Kolektibilitas merupakan keadaan pembayaran kembali pokok dan bunga kredit nasabah serta tingkat kemungkinan diterimanya kembali dana yang ditanamkan dalam surat berharga atau penanaman lainnya. Non Performing Loans (NPL) merupakan 
rasio kredit yang diberikan bermasalah dengan total kredit

5. Tingkat Rentabilitas

Penilaian terhadap faktor rentabilitas menggunakan Return on Asset (ROA) dan BOPO. Rasio pertama adalah rasio laba sebelum pajak terhadap rata-rata volume usaha yang disebut dengan rasio Return on Asset (ROA). Rasio kedua yang digunakan dalam penilaian faktor rentabilitas adalah rasio biaya operasional terhadap pendapatan operasional (BOPO).

\section{Tingkat Likuiditas}

Suatu bank dikatakan likuid apabila bank dapat memenuhi kewajiban, dapat membayar semua deposantnya, serta dapat memenuhi permintaan kredit yang diajukan tanpa terjadi penangguhan.

7. Rasio Permodalan

Penilain terhadap rasio permodalan didasarkan pada rasio modal terhadap Aktiva Tertimbang Menurut Resiko (ATMR) dan Peraturan Bank Indonesia Nomor 8/18/PBI/2006 Tanggal 5 Oktober 2006 Tentang Kewajiban Penyediaan Modal Minimum Bank Perkreditan Rakyat.

Modal merupakan salah satu faktor penting bagi bank dalam rangka pengembangan usaha dan menampung risiko kemungkinan kerugian. Modal Sendiri Bank (Equity Fund) adalah sejumlah uang tunai yang telah disetorkan pemilik dan sumber -sumber lainnya yang berasal dari dalam bank itu sendiri; terdiri dari modal inti dan modal pelengkap.

\section{Penelitian Terdahulu}

Astuti (2003) tentang Penilaian Tingkat Perkembangan Kesehatan Bank dengan Menggunakan Analisis CAMEL Studi Kasus pada BPR Artha Sumber Arum Yogyakarta Periode 2003-2006.
Hasil dari penelitian tersebut menunjukkan kinerja keuangan berupa rasio permodalan tertinggi pada periode 2003 sebesar 17,90 dan terendah pada periode 2006 sebesar 12,22. Rasio aktiva produktif yang diklasifikasikan dengan aktiva produktif tertinggi pada periode 2003 sebesar 7,5 dan terendah pada periode 2005 sebesar 14,4. Rasio PPAD terhadap PPAPWD tertinggi pada periode 2003 dan 2004 sebesar 100 dan terendah pada periode 2006 sebesar 93,90. Rasio manajemen selama periode 2003 sampai dengan 2006 menunjukkan sama sebesar 100. Rasio ROA tertinggi pada periode 2003 sebesar 10,15 dan terendah pada periode sebesar 0,28. Rasio BOPO tertinggi pada periode 2003 sebesar 75,77 dan terendah pada periode 2006 sebesar 112,80 . Cash ratio tertinggi pada periode 2006 sebesar 26,90 dan terendah pada periode 2004 sebesar 17,25. Rasio LDR tertinggi pada periode 2006 sebesar 74,43 dan terendah pada periode 2003 sebesar 85,26. Secara keseluruhan, trend analisis CAMEL terbaik terjadi pada periode 2003 dengan jumlah factor CAMEL 91,20 dengan trend 100 dan berpredikat sehat. Penelitian terdahulu memiliki persamaan dengan penelitian ini yaitu mengenai penelitian kesehatan bank dalam hal ini berkaitan dengan kinerja keuangan bank. Perbedaan penelitian terdahulu dengan penelitian ini yaitu terletak pada objek penelitian, penelitian terdahulu pada BPR Artha Sumber Arum Yogyakarta periode 2003 2006 sedangkan penelitian ini pada PD. BPR Dana Mitra Sejahtera periode 2012-2014.

Penelitian lainnya oleh Sugiarto yang meneliti "Analisis Rasio Keuangan Terhadap Non Performing Loan Pada Perusahaan Daerah Bank Perkreditan Rakyat Badan Kredit Kecamatan SeJawa Tengah Periode 2008-2009". Pengukuran kinerja keuangan PD. BPR BKK Se-Jawa Tengah yang terangkum dalam BOPO, CAR, CR, LDR, NIM, RAO, ROE terhadap NPL berdasarkan 
penelitian dan pengukuran ini dapat dikatakan telah mewakili semua aspek keuangan karena telah mencakup segi rentabilitas dalam hal ini dinyatakan dalam perhitungan BOPO dan ROE, segi permodalan yang dinyatakan dengan CAR, segi efektifitas usaha yang dinyatakan dengan NIM dan segi likuiditas yang dinyatakan dengan $\mathrm{CR}$ dan LDR.

\section{METODE PENELITIAN}

\section{Subjek dan Objek Penelitian}

Penelitian ini dilakukan pada PD BPR BKK KEBUMEN DAN PT BPR DANA MITRA SEJAHTERA KEBUMEN, sedangkan objek penelitian ini adalah rasio keuangan yang digunakan untuk menganalisis kinerja keuangan bank.

\section{Sumber Data}

Data yang digunakan dalam penelitian ini menggunakan data sekunder, berupa data-data yang sudah dimiliki pada kedua BPR tersebut yang meliputi:

1. Laporan keuangan PD BPR BKK KEBUMEN DAN PT BPR DANA MITRA SEJAHTERA KEBUMEN (neraca, laporan laba rugi ) tahun 20122014.

2. Tinjauan historis dan struktur organisasi PD BPR BKK KEBUMEN DAN PT BPR DANA MITRA SEJAHTERA KEBUMEN.

\section{Teknik Analisis Data}

1. Untuk mengetahui kinerja bank yang ditinjau dari faktor kecukupan permodalan berdasarkan tinggi rendahnya rasio CAR (Capital Adequensy Ratio), yang merupakan rasio (perbandingan) antara Modal (Modal Inti dan Pelenkap), dengan Aktiva Tertimbang Menurut Rasio (ATMR). Rumusnya sebagai berikut:

$$
C A R=\frac{\text { ModalBank }(\text { Inti }+ \text { Pelengkap })}{A T M R} X 100 \%
$$

Nilai CAR dikonversikan menjadi nilai kredit (NK) dengan rumus:

$$
\mathrm{NK}=\frac{C A R}{0,1}+1 \text { (maksimal 100) }
$$

2. Untuk mengetahui tingkat kesehatan bank ditinjau dari faktor Kualitas Aktifa Produktif (asset quality) dinilai berdasarkan tinggi rendahnya rasio 2 komponennya: yaitu rasio Kualitas Aktifa Produktif (KAP) dan rasio Penyisihan Penghapusan Aktifa Produktif (PPAP).

a. Rasio aktiva yang diklasifikasikan terhadap aktiva produktif,

dihitung KAP dengan rumus:

$$
K A P=\frac{\text { aktiva produktif } y g \text { diklasifikasi }}{\text { Total aktiva produkstif }} \times 100 \%
$$

Nilai KAP dikonversikan mnjadi Nilai Kredit (NK) dengan rumus:

$$
N K=\frac{22,5 \%-\text { rasio } K A P}{0,15 \%} \times 100 \%
$$

b. Rasio Penyisihan Penghapusan Aktifa Produktif yang dibentuk Bank terhadap penyisihan penghapusan aktiva produktif yang wajib

dibentuk dengan rumus sebagai berikut:

$$
\text { 1) } P P A P=\frac{\text { PPAP dibentuk bank }}{\text { PPAP yang wajib dibentuk }} \times 100 \%
$$

Nilai PPAP dikonversikan menjadi Nilai Kredit (NK) dengan

rumus:

$\mathrm{NK}=$ Rasio PPAP X 1 ( maksimal 100)

3. Untuk mengetahui tingkat kesehatan bank ditinjau dari faktor Manajemen yang diambil berdasarkan NPL yang merupakan cerminanan dari manajemen resiko bagi BPR. Faktor manajemen dinilai atas dasar 25 pokok pertanyaan dan terdiri dari 2 komponen manajemen sebagai berikut: 


\begin{tabular}{|l|l|}
\hline Komponen & Pertanyaan / Pernyataan \\
\hline Manajemen Umum (4 aspek) & 10 Pertanyaan / Pernyataan \\
\hline $\begin{array}{l}\text { 2. Strategi } \\
\text { 3. Sistem }\end{array}$ & 1 \\
4. Kepemimpinan & 3 \\
\hline Manjemen Resiko ( 5 Aspek) & 15 Pertanyaan / Pernyataan \\
\hline $\begin{array}{l}\text { 1. Resiko Likuiditas } \\
\text { 2. Resiko Kredit }\end{array}$ & 2 \\
3. Resiko Operasional & 3 \\
4. Resiko Hukum & 3 \\
5. Resiko Pemilik/Pengurus & 4 \\
\hline
\end{tabular}

4. Untuk mengetahui tingkat kesehatan bank ditinjau dari faktor rentabilitas (earning) merupakan kemampuan bank untuk menghasilkan keuntungandinilai dari tinggi rendahnya rasio Beban Operasional terhadap Pendapatan Operasional (BOPO).

a. Rasio Return on Asset (ROA)

1) Rasio Return on Asset (ROA), merupakan rasio (perbandingan) antara laba bersih dengan total asset. Rumusnya adalah sebaga berikut:

$$
R O A=\frac{\text { Laba bersih }}{\text { Total aset }} \times 100 \%
$$

Nilai ROA dikonversikan menjadi Nilai Kredit (NK) dengan rumus:

$$
N K=\frac{\text { Rasio Roa }}{0,015} \times 100 \% \text { (maksimal 100) }
$$

b. Rasio Beban Operasional terhadap Pendapatan Operasional (BOPO)

1) Rasio Beban Operasional terhadap Pendapatan Operasional (BOPO), merupakan rasio (perbandingan) antara biaya operasional dengan pendapatan operasional. Rumusnya adalah sebagai berikut:

$$
B O P O=\frac{\text { Biaya operasional }}{\text { Pendapatan operasional }} \times 100 \%
$$

Nilai BOPO dikonversikan menjadi Nilai Kredit (NK) dengan rumus:

$$
N K=\frac{100-\text { rasio } B O P O}{0,08} \times 100 \%(\text { maksimal } 100)
$$

5. Untuk kinerja keuangan bank ditinjau dari faktor likuiditas (liquidity)dinilai berdasarkan tinggi rendahnya rasio 2 komponen, yaitu rasio Cash Ratio (CR) dan rasio Loan to Deposit Ratio (LDR).

a. Rasio Cash Ratio (CR)

1) Rasio Cash Ratio (CR), merupakan rasio (perbandingan) antara alat likuid terhadap hutang lancar. Rumusnya adalah sebagai berikut:

$$
C R=\frac{\text { Aktiva lancar }}{\text { Hutang lancar }} \times 100 \%
$$

b. Rasio Loan to Deposit Ratio (LDR)

1) Rasio Loan to Deposit Ratio (LDR), merupakan (perbandingan) antara jumlah kredit yang diberikan (jumlah seluruh pendapatan) dengan jumlah dana yang diterima (jumlah dana yang dihimpun dari pihak ketiga). Rumusnya adalah sebagai berikut:

$$
L D R=\frac{\text { Total kredit yang diberikan }}{\text { Dana yang diterima }} \times 100 \%
$$

6. Penilaian Tingkat Kesehatan Bank Secara Keseluruhan

Tingkat kinerja keuangan bank secara keseluruhan pada PD BPR BKK KEBUMEN DAN PT BPR DANA MITRA SEJAHTERA KEBUMEN dari tahun 2012-2014, dianalisis dengan membandingkan rasio-rasio yang diperoleh, umtuk kemudian dibandingkan hasilnya dengan kriteria kinerja bank dari Bank Indonesia (BI).

\section{HASIL PENELITIAN DAN PEMBAHASAN}

\section{Pembahasan}

1. CAR

CAR/KPMM PD. BPR BKK KEBUMEN

\begin{tabular}{|l|l|l|}
\hline Tahun & Rasio KPMM & Keterangan \\
\hline 2012 & $14,97 \%$ & Sehat $\quad: \geq 8,0 \%$ \\
& & $\begin{array}{l}\text { Kurang Sehat }: \geq 6,5 \%-<8,0 \% \\
\text { Tidak Sehat } \quad:<6,5 \%\end{array}$ \\
\hline 2013 & $15,57 \%$ & \\
\hline 2014 & $15,48 \%$ & \\
\hline
\end{tabular}

Dalam 3 (tiga) tahun berturutturut PD. BPR BKK Kebumen memiliki rasio CAR/KPMM yang sehat karena rasionya berada diatas $8 \%$ sebagaimana ditetapkan oleh BI/OJK 
5. BOPO

BOPO PD. BPR BKK Kebumen

\begin{tabular}{|l|l|l|}
\hline Tahun & Rasio BOPO & Keterangan \\
\hline 2012 & $76,08 \%$ & $\begin{array}{l}\text { Sehat } \quad: \leq 93,52 \% \\
\text { Cukup Sehat }:>93,52 \%-\leq 94,72 \%\end{array}$ \\
\cline { 1 - 2 } 2013 & $71,30 \%$ & $\begin{array}{l}\text { Kurang Sehat }:>94,72 \%-\leq 95,92 \% \\
\text { Tidak Sehat } \quad:>95,92 \%\end{array}$ \\
\hline 2014 & $69,02 \%$ & \\
\hline
\end{tabular}

Dari tabel tersebut diatas nampak bahwa BOPO PD. BPR BKK Kebumen dalam keadaan sehat selama 3 (tiga) tahun penelitian dan selalu mengalami perbaikan yang ditandai dengan menurunnya rasio BOPO.

BOPO PT. BPR Dana Mitra Sejahtera

\begin{tabular}{|l|l|l|}
\hline Tahun & Rasio BOPO & Keterangan \\
\hline 2012 & $63,15 \%$ & $\begin{array}{l}\text { Sehat }: \leq 93,52 \% \\
\text { Cukup Sehat }:>93,52 \%-\leq 94,72 \%\end{array}$ \\
\hline 2013 & $80,48 \%$ & $\begin{array}{l}\text { Kurang Sehat : }>94,72 \%-\leq 95,92 \% \\
\text { Tidak Sehat }:>95,92 \%\end{array}$ \\
\hline 2014 & $83,42 \%$ & \\
\hline
\end{tabular}

Dari tabel tersebut diatas nampak bahwa PT. BPR Dana Mitra Sejahtera memiliki rasio BOPO yang sehat, namun demikian selama 3 (tiga) tahun penelitian mengalami penurunan yang ditandai degan meningkatnya rasio BOPO dari tahunn 2012 sebesar $63,15 \%$ menjadi $83,42 \%$ pada akhir tahun 2014.

6. $\mathrm{CR}$

CR PD. BPR BKK Kebumen

\begin{tabular}{|l|l|l|}
\hline Tahun & Rasio CR & Keterangan \\
\hline 2012 & $26,06 \%$ & $\begin{array}{l}\text { Sehat } \quad: \geq 4,05 \% \\
\text { Cukup Sehat }: \geq 3,30 \%-<4,05 \%\end{array}$ \\
\hline 2013 & $21,66 \%$ & $\begin{array}{l}\text { Kurang Sehat }: \geq 2,55 \%-\leq 3,30 \% \\
\text { Tidak Sehat } \quad:<2,55 \%\end{array}$ \\
\hline 2014 & $29,75 \%$ & \\
\hline
\end{tabular}

Dari tabel tersebut diatas nampak bahwa selama 3 (tiga) tahun penelitian rasio kecukupan alat likuiditas PD. BPR BKK Kebumen dalam posisi sehat yang ditandai rasio $\mathrm{CR}$ berada diata standar minimal BI/OJK.
CR PT. BPR Dana Mitra Sejahtera

\begin{tabular}{|l|l|l|}
\hline Tahun & Rasio CR & Keterangan \\
\hline 2012 & $15,96 \%$ & Sehat $\quad: \geq 4,05 \%$ \\
\hline 2013 & $33,04 \%$ & $\begin{array}{l}\text { Cukup Sehat }: \geq 3,30 \%-<4,05 \% \\
\text { Kurang Sehat }: \geq 2,55 \%-\leq 3,30 \%\end{array}$ \\
\hline 2014 & $14,06 \%$ & \begin{tabular}{l} 
Tidak Sehat $\quad:<2,55 \%$ \\
\hline
\end{tabular} \\
\hline
\end{tabular}

Dalam 3 (tiga) tahun penelitian rasio CR PT. BPR Dana Mitra Sejahtera dalam keadaan sehat dan terjaga likuiditasnya, namun demikian terdapat fluktuatif yang cukup signifikan yaitu pada tahun 2013 naik dari 15,96\% pada tahun 2012 menjadi $33,04 \%$ dan kembali turun menjadi 14,06\% pada akhir tahun 2014.

7. LDR

LDR PD. BPR BKK Kebumen

\begin{tabular}{|c|c|c|c|}
\hline Tahun & Rasio LDR & Keterangan & \\
\hline 2012 & $98,55 \%$ & \multirow{3}{*}{\multicolumn{2}{|c|}{$\begin{array}{l}\text { Sehat } \quad: \leq 94,75 \% \\
\text { Cukup Sehat }:>94,75 \%-\leq 98,50 \% \\
\text { Kurang Sehat }:>98,50 \%-\leq 102,25 \% \\
\text { Tidak Sehat } \quad:>102,25 \%\end{array}$}} \\
\hline 2013 & $99,05 \%$ & & \\
\hline 2014 & $99,09 \%$ & & \\
\hline
\end{tabular}

Dalam kurun waktu 3 (tiga) tahun penelitian rasio LDR PD. BPR BKK Kebumen dalam kondisi kurang sehat dimana rasio LDR lebih besar dari syarat standar BI/OJK, hal ini menandakan ekspansi kredit yang kurang diimbangi dengan penghimpunan dana pihak ketiga.

LDR PT. BPR Dana Mitra Sejahtera

\begin{tabular}{|c|c|c|c|}
\hline Tahun & Rasio LDR & Keterangan & \\
\hline 2012 & $81,23 \%$ & \multirow{3}{*}{\multicolumn{2}{|c|}{$\begin{array}{ll}\text { Sehat } & : \leq 94,75 \% \\
\text { Cukup Sehat } & :>94,75 \%-\leq 98,50 \% \\
\text { Kurang Sehat }:>98,50 \%-\leq 102,25 \% & \\
\text { Tidak Sehat }:>102,25 \%\end{array}$}} \\
\hline 2013 & $71,08 \%$ & & \\
\hline 2014 & $82,69 \%$ & & \\
\hline
\end{tabular}

Dalam kurun waktu 3 (tiga) tahun penelitian, LDR PT. BPR Dana Mitra Sejahtera selalu sehat dimana rasio LDR selalu di bawah batas maksimal ketentuan BI/OJK. 
8. NPL

NPL Nett

\begin{tabular}{|l|l|l|}
\hline Tahun & PD. BPR BKK Kebumen & PT. BPR Dana Mitra Sejahtera \\
\hline 2012 & $4,43 \%$ & $4,22 \%$ \\
\hline 2013 & $3,92 \%$ & $4,16 \%$ \\
\hline 2014 & $3,27 \%$ & $7,37 \%$ \\
\hline
\end{tabular}

Untuk memberikan scoring menggunakan patokan dasar apabila NPL maksimal 5\% maka nilai adalah 100 dan setiap penambahan $1 \%$ nilai dikurangi 0,95 .

Dalam kurun waktu 3 (tiga) tahun penelitian NPL kedua BPR dalam kondisi yang memenuhi standar kepatuhan BI/OJK yaitu maksimal 5\%. Dari tabel diatas dapat dilihat bahwa PD. BPR BKK Kebumen mengalami perbaikan kualitas aktiva produktif dimana NPL selalu menurun sedangkan PT. BPR Dana Mitra Sejahtera mengalami penurunan kualitas aktiva produktif yaitu dengan meningkatannya NPL yang cukup signifikan dari tahun 2012 sebesar 4,22\% menjadi 7,37\% pada akhir 2014.

9. Rata-Rata Rasio

Rata-rata Rasio

\begin{tabular}{|c|c|c|c|c|c|c|}
\hline \multirow{2}{*}{ NO } & \multirow{2}{*}{ PERIODE } & \multirow{2}{*}{ RASIO } & \multicolumn{2}{|c|}{ PD. BPR BKK KEBUMEN } & \multicolumn{2}{|c|}{ PT. BPR DANA MITRA } \\
\hline & & & \begin{tabular}{|l|} 
RATA-RATA \\
\end{tabular} & KETERANGAN & RATA-RATA & KETERANGAN \\
\hline & $2012 \cdot 2014$ & CAR & $15,21 \%$ & Sehat & $12,70 \%$ & Sehat \\
\hline & $2012 \cdot 2014$ & KAP & $5,68 \%$ & Sehat & $5,27 \%$ & Sehat \\
\hline & $2012 \cdot 2014$ & PPAP & $100,00 \%$ & Sehat & $95,68 \%$ & Sehat \\
\hline & $2012-2014$ & ROA & $3,64 \%$ & Sehat & $2,24 \%$ & Sehat \\
\hline & 2012 - 2014 & BOPO & $72,13 \%$ & Sehat & $75,68 \%$ & Sehat \\
\hline & 2012 - 2014 & $C R$ & $25,82 \%$ & Sehat & $21,02 \%$ & Sehat \\
\hline & $2012-2014$ & LDR & $98,90 \%$ & Kurang Sehat & $78,33 \%$ & Sehat \\
\hline & $2012 \cdot 2014$ & NPL & $3,87 \%$ & Patuh & $5,25 \%$ & Cukup Patuh \\
\hline
\end{tabular}

10. Penilaian Tingkat Kesehatan BPR Penilaian Tingkat Kesehatan BPR

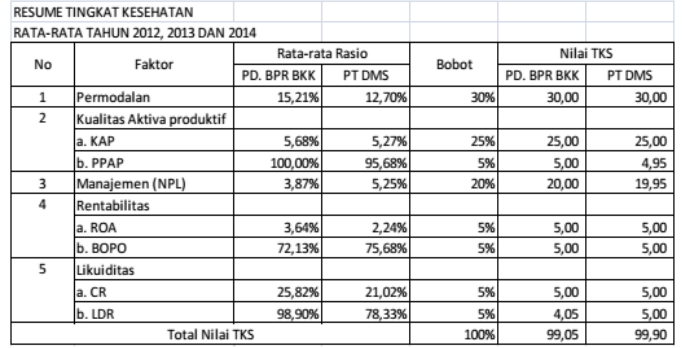

Dalam kurun waktu 3 (tiga) tahun penelitian secara rata-rata PT. BPR Dana Mitra Sejahtera mempunyai nilai lebih baik dari PD. BPR BKK Kebumen.

\section{KESIMPULAN DAN SARAN}

\section{Kesimpulan}

1. CAR Pada rasio kecukupan modal, pada akhir tahun 2014 baik PD. BPR BKK Kebumen maupaun PT. BPR Dana Mitra Sejahtera masuk dalam kategori SEHAT, dimana rasio CAR keduanya di atas angk $8 \%$ sebagaimana dipersyaratkan oleh Bank Inonesia/OJK, namun demikian ratio pada PD. BPR BKK Kebumen mengalami penurunan dari tahun 2012 sampai tahun 2014 sedangkan PT. BPR Dana Mitra Sejahtera mengalami kenaikan pada tahun 2012 ke 2014.

2. Rasio KAP dari kedua BPR pada akhir tahun 2014 tergolong SEHAT dimana ratio KAP berada dibawah ketentuan yaitu maksimal untuk sehat adalah $10,35 \%$. Dilihat dari pergerakan rasio ini PD. BPR BKK Kebumenpada tahun 2012 sampai 2014 semakin membaik dengan menurunnya nilai rasio KAP setiap tahunnya namun masih dalam kriteria sehat dibawah ketentuan rasio maksimal 10,35\%, sedangkan pada PT. BPR Dana Mitra Sejahtera terus mengalami penurunan dari tahun 2012 sampai 2014 dengan meningkatnya nilai rasio KAP namun masih dalam kriteria sehat dibawah ketentuan rasio maksimal 10,35\%.

3. Untuk ratio PPAP PD. BPR BKK Kebumen sesuai dengan ketentuan Bank Indonesia/OJK telah memenuhi syarat minimal $100 \%$ dalam kategori sehat. Sedangkan PT BPR Dana Mitra Sejahtera tahun 2012 dan 2014 sudah sesuai dengan aturan BI/OJK yaitu sehat minimal $100 \%$, namun tahun 2013 mengalami penurunan yaitu $87,03 \%$ karena tidak semua kolektibilitas non lancar/kredit dijamin dengan nilai agunan yang dikuasai bank. 
4. Rasio ROA PD. BPR BKK Kebumen masuk kategori SEHAT dan cenderung meningkat dari tahun 2012 samapai dengan 2014, sedangkan pada PT. BPR Dana Mitra Sejahtera masuk kategori sehat namunmengalami penurunan yang signifikan dari tahun ke tahun.

5. Rasio BOPO dari kedua BPR masuk dalam kategori SEHAT dimana rasio kedua BPR berada dibawah ketentuan kriteria sehat yaitu maksimal 93,52\%. Namun demikian PD. BPR BKK Kebumen mengalami perbaikan kinerja dimana rasio tahun 2014 lebih kecil daripada tahun 2013 dan 2012, sedangkan PT. BPR Dana Mitra Sejahtera mengalami penurunan dimana rasio tahun 2014 lebih besar dari tahun 2013 maupun 2012.

6. Persediaan alat likuiditas kedua BPR termasuk kategori SEHAT dimana rasio keduanya diatas ketentuan minimal yaitu 4,05\%. Namun demikian PD. BPR BKK Kebumen mengalami peningkatan kinerja dimana rasio tahun 2014 lebih besar dari tahun 2013 walaupun turun dari thun 2012, sedangkan PT. BPR Dana Mitra Sejahtera mengalami penurunan yang signifikan pada akhir tahun 2014 baik dari tahun 2012 maupun dari tahun 2013.

7. Rasio LDR kedua BPR masuk kategori SEHAT dimana rasio berada dibawah ketentuan maksimal $94.75 \%$. Namun demikian PD. BPR BKK Kebumen mengalami perbaikan dimana rasio tahun 2014 lebih kecil dari tahun 2013 dan 2012, sedangkan PT. BPR Dana Mitra Sejahtera pada akhir 2014 mengalami perbaikan dari tahun 2012 namun menurun jika dibanding tahun 2013.
8. Pada pemenuhan kepatuhan yang didasarkan pada faktor NPL PD. BPR BKK Kebumen pada tahun 2014 telah memenuhi standar maksimal $5 \%$ dan mengalami perbaikan kinerja dimana NPL tahun 2014 lebih kecil dari tahun 2013 dan 2012, sedangkan PT. BPR Dana Mitra Sejahtera mengalami penurunan dimana NPL tahun 2014 lebih besar dari tahun 2013 dan 2012.

9. Secara umum rata-rata rasio PD. BPR BKK Kebumen sehat dan patuh aturan hanya perlu perbaikan pada faktor LDR, dan PT. BPR Dana Mitra Sejahtera rata-rata rasionya sehat hanya perlu perbaikan pada faktor kepatuhan dengan menurunkan NPL.

10. Dalam kurun waktu 3 (tiga) tahun penelitian nilai PT. BPR Dana MitraSejahtera lebih baik dari PD. BPR BKK Kebumen.

Dari indikator-indikator diatas PD.

BPR BKK Kebumen secara umum mengalami peningkatan, sedangkan PT. BPR Dana Mitra Sejahtera mengalami penurunan, dan hal tersebut merupakan dampak penurunan kualitas aktiva produktif, dimana ketika NPL suatu bank termasuk BPR tinggi maka bank akan mengalami kekurangan alat likuiditas, penurunan perolehan laba, dan terjadi pembengkakan biaya operasional karena bank wajib membentuk PPAP $100 \%$.

\section{Saran}

a. Bagi BPR

PD.BPR BKK Kebumen dan PT. Dana Mitra Sejahtera memiliki tingkat kesehatan dengan menganalisis rasio keuangan CAR/KPMM, KAP, PPAP, BOPO, ROA, CR, dan LDR . PD. BPR BKK Kebumen pada rasio LDR mendapat predikat kurang sehat karena penghimpunan dana pihak ketiga kurang antara kredit dengan dana 
pihak ketiga tidak seimbang, seharusnya bank tidak terlalu melakukan ekspansi atau penyaluran kredit kepada nasabah.

PT. BPR Dana Mitra Sejahtera pada rasio CAR mengalami penurunan yang cukup signifikan dari tahun 2012 sampai tahun 2014. Dengan keadaan itu bank seharusnya mampu menekankan kredit yang dapat menjadikan kredit bermasalah dan juga harus mampu meningkatkan jumlah aktiva produktif, sehingga akan menambah pendapatan bank yang akhirnya laba akan meningkat.

PT BPR Dana Mitra Sejahtera pada rasio NPL tahun 2014 mengalami peningkatan $7,37 \%$ yang melebihi standar minimal 5\%. Dengan keadaan itu bank seharusnya melakukan penanganan kredit-kredit yang bermasalah/ kredit non lancar supaya kredit tersebut menjadi lancar.

b. Bagi Nasabah

Bank yang sehat dengan rasio CR dan LDR yang sehat maka nasabah merasa nyaman dan aman untuk penempatan dananya. Dengan rasio KAP dan PPAP yang juga diikuti rasio NPL yang rendah maka debitur mempunyai kesempatan untuk mengembangkan usaha melalui perkreditan.

c. Bagi Peneliti Selanjutnya

Untuk penelitian dengan tema yang sama sebaiknya agar bisa menambah jumlah sampel dan memasukan komponen rasio keuangan selain yang tertuang dalam Tingkat Kesehatan Bank.

\section{DAFTAR PUSTAKA}

Astuti, Ratna Tri. (2003). Penilaian Perkembangan Kesehatan Bank dengan Menggunakan CAMEL Studi Kasus pada BPR Artha Mitra Sumber Arum Periode 2003-
2006. Skripsi. Yogyakarta: Akuntansi FISE UNY.

Peraturan Bank Indonesia Nomor 8/18/PBI/2006 tanggal 5 Oktober tahun2006 tentang Kewajiban Penyediaan Modal Minimum Bank Perkreditan Rakyat.

Sugiarto, Danar. (2010). Analisis Rasio Keuangan Terhadap Non Perfoming Loan Pada Perusahaan Daerah Bank Perkreditan Rakyat Badan Kredit Kecamatan se- Jawa Tengah Periode 2008-2009. Tesis. Semarang: STIE Dharma Putra.

Susilo, Sri Y, dkk. (2000). Bank dan Lembaga Keuangan Lainnya. Jakarta: Salemba Empat.

Undang-Undang Republik Indonesia Nomor 10 Tahun 1998 tentang Perbankan. 